\title{
PENERAPAN TEKNOLOGI LAMPU CELUP BAWAH AIR (LACUBA) UNTUK NELAYAN BAGAN TANCAP GUNA MENINGKATKAN KAPASITAS IKAN TANGKAPAN
}

\author{
Fitri Imansyah ${ }^{1}$, M. Iqbal Arsyad ${ }^{2}$, Jannus Marpaung ${ }^{3}$, Redi Ratiandi ${ }^{4}$, Nedi Suryadi ${ }^{5}$ \\ 1)2334)5) Jurusan Teknik Elektro, Fakultas Teknik, Universitas Tanjungpura \\ Jln. Prof. H. Hadari Nawawi, Pontianak, Indonesia
}

\begin{abstract}
Corresponding Author: Fitri Imansyah ${ }^{1}$ Email : fitri.imansyah@ee.untan.ac.id
Abstrak: Bagan tancap merupakan salah satu jenis alat tangkap yang menggunakan lampu sebagai alat bantu pengumpul ikan. Cahaya lampu diharapkan dapat merangsang ikan untuk datang dan berkumpul disekitar sumber cahaya sampai pada suatu catchable area tertentu, lalu penangkapan dilakukan dengan alat jaring maupun pancing. Penggunaan lampu untuk penangkapan ikan saat ini berkembang pesat, hampir semua alat tangkap menggunakan lampu sebagai alat bantu pengumpul ikan. Aplikasi teknologi ini bertujuan untuk meningkatkan hasil tangkapan ikan nelayan bagan tancap di Kecamatan Sungai Kunyit melalui penerapan teknologi lampu celup bawah air (lacuba) berbasis lampu LED. Metode eksperimen murni yang diterapkan pada bagan tancap dengan Lacuba menggunakan intensitas dan warna tertentu dengan tujuan memberikan hasil tangkapan yang terbaik. Pemakaian lampu celup bawah air pada alat penangkapan ikan, dapat diketahui bahwa sumber kekuatan sumber cahaya dan intensitas cahaya mempunyai pengaruh besar dalam usaha memikat ikan. Demikian juga dengan letak lampu di atas permukaan air (surface lamp) dan di dalam air (underwater lamp) serta jarak sumber cahaya dengan permukaan air. Pada intensitas cahaya yang sama tetapi pada jarak yang berbeda akan memberikan hasil tangkapan yang berbeda akan memberikan hasil tangkapan yang berbeda pula hasil tangkapan yang diberikan. Hal ini dibuktikan dengan meningkatnya hasil tangkapan ikan sekitar 65\% dibandingkan dengan menggunakan lampu petromak. Dalam memanfaatkan teknologi tepat guna berupa lampu celup bawah air diharapkan dapat mewujudkan modernisasi usaha perikanan yang diikuti alokasi sarana dan prasarana yang diperlukan agar nelayan mampu mengembangkan usahanya sebagai usaha yang tangguh dan memiliki daya saing yang kuat, serta meningkatkan produktivitas dan modernisasi usaha sehingga dicapai perbaikan sistem pengembangan usaha perikanan serta pengolahan dan pemanfaatan sumber daya alam yang ada di lokasi usaha perikanan agar ketersediaan ikan selalu terpenuhi.
\end{abstract}

Kata kunci: Lacuba, bagan tancap, intensitas cahaya, moderinisasi perikanan

\begin{abstract}
Abstarct: Bagan Tancap is one type of fishing gear that uses lights as a tool to collect fish. The use of lights for fishing is currently growing rapidly, almost all fishing gears use lights as a means of collecting fish. The application of this technology aims to increase the catch of fish from tancap fishermen in Sungai Kunyit District through the application of LED light-based underwater light (lacuba) technology. The pure experimental method applied to the tancap chart with Lacuba uses a certain intensity and color with the aim of providing the best catch. Using underwater immersion lights in fishing gear, it can be seen that the source of the power of the light source and the intensity of the light have a big influence in the effort to attract fish. Likewise, the location of the lamp above the
\end{abstract}


surface of the water (surface lamp) and in the water (underwater lamp) and the distance of the light source from the water surface. At the same light intensity but at different distances it will give different catches that will give different catches the catch given. This is evidenced by the increase in fish catches of about 65\% compared to using petromak lamps. In utilizing appropriate technology in the form of underwater submerged lights, it is hoped that the modernization of fisheries business is followed by the allocation of facilities and infrastructure needed so that fishermen are able to develop their business as a tough and competitive business, as well as increase productivity and business modernization in order to achieve system improvement. developing fishery businesses as well as processing and utilizing natural resources in fishery business locations so that fish availability is always fulfilled.

Keywords: Lacuba, perimeter chart, light intensity, fisheries moderation

\section{Pendahuluan}

Setiap usaha penangkapan ikan pada prinsipnya adalah mendapatkan ikan sebanyak mungkin pada suatu daerah penangkapan. Keberhasilan setiap usaha penangkapan ikan perlu ditunjang dengan pengetahuan yang cukup mengenai tingkah laku ikan (fish behaviour) dan untuk menemukan serta mengumpulkan gerombolan ikan dapat ditempuh dengan berbagai cara, mulai dari cara yang konvensional hingga penggunaan alat-alat elektronik modern seperti lampu dalam air. Penggunaan lampu dimanfaatkan sebagai alat bantu penangkapan ikan dengan maksud agar ikan terkonsentrasi pada suatu tempat, dimana alat penangkapan ikan dengan mudah dioperasikan. Salah satu cara yang umum digunakan oleh para nelayan dalam menarik, menggiring ikan serta mengumpulkan ikan adalah dengan menggunakan lampu (Balai Besar Pengembangan Penangkapan Ikan, 2007).

Bagan tancap adalah alat penangkapan ikan yang termasuk dalam klasifikasi jaring. Bagan sudah sejak lama dikenal oleh masyarakat nelayan dalam mengeksploitasi sumberdaya perairan laut, tetapi dalam pengembangannya masih sangat sederhana. Hasil tangkapan dari alat tangkap bagan umumnya terdiri atas jenis ikan yang berenang dekat permukaan perairan dan tertarik pada cahaya serta hidup bergerombol. Bagan adalah salah satu jenis alat tangkap yang digunakan nelayan untuk menangkap ikan pelagis kecil. Bagan dalam perkembangannya telah banyak mengalami perubahan baik bentuk maupun ukuran yang dimodifikasi sedemikian rupa sehingga sesuai dengan daerah penangkapannya (Sudirman dan Natsir, 2011). Berdasarkan cara pengoperasiannya bagan dikelompokkan dalam jaring angkat (lift net), namun karena menggunakan cahaya lampu untuk mengumpulkan ikan maka disebut juga light fishing. Berdasarkan mobilitasnya, alat tangkap bagan dibagi dua yaitu bagan tancap dan bagan apung (Brown, A., dkk, 2013). Bagan tancap sifatnya menetap sedangkan bagan apung dapat berpindah dari satu daerah penangkapan ke daerah penangkapan lainnya.

Lacuba (Lampu Celup Bawah Air) merupakan lampu yang dipakai dalam air untuk menarik perhatian ikan. Ikan tertarik pada cahaya melalui penglihatan (mata) dan rangsangan melalui otak (pineal region pada otak). Peristiwa ikan tertarik pada cahaya disebut fototaksis. Dengan demikian, ikan yang tertarik oleh cahaya hanyalah ikan-ikan fototaksis, yang umumnya adalah ikan-ikan yang tidak tertarik oleh cahaya atau menjauhi cahaya biasa disebut fotophobi. Ada beberapa alasan mengapa ikan tertarik oleh cahaya antara lain adalah penyesuaian intensitas cahaya dengan kemampuan mata ikan untuk menerima cahaya. Dengan demikian, kemampuan ikan untuk tertarik pada suatu amber cahaya sangat berbedabeda. Ada ikan yang senang pada intensitas cahaya yang rendah, tetapi ada pula ikan yang senang pada intensitas yang tinggi. Namun ada ikan yang mempunyai kemampuan untuk tertarik oleh cahaya mulai dari intensitas yang rendah sampai 
intensitas yang tinggi (Bustari, 2004).

Permasalahn mitra dalam kegiatan pengabdian kepada masyarat nelayan Kecamatan Sui Kunyit Kabupaten Mempawah ini masih sangat tradisional yang hanya menggunakan lampu petromak/strongkin (pressure lamp) untuk mengumpulkan ikan, yang dioperasikan dimalam hari. Namun secara teknis dalam perkembangannya penggunaan cahaya lampu petromaks hanya dapat dioperasikan di atas permukaaan air. Kelemahannya adalah karena seringnya faktor angin dan cuaca yang buruk menyebabkan penggunaan lampu petromaks tidak dapat dilakukan, selain itu jumlah cahaya yang masuk ke dalam perairan menjadi sedikit karena adanya pemantulan dan bahkan sinar yang dihasilkan tidak stabil yang pada gilirannya tidak memberikan hasil tangkapan yang memuaskan bagi nelayan. Oleh karena itu dibutuhkan suatu sumber cahaya yang lebih efektif untuk menarik perhatian ikan dan mampu mengumpulkan ikan di sekitar daerah tangkapan kelong (bagan tancap).

Salah satu cara untuk mengurangi efek pemantulan dan tidak stabilnya cahaya lampu adalah dengan cara memasukkannya ke dalam air. Lampu yang dipakai adalah lampu listrik yang dirakit agar kedap air. Lacuba merupakan alat pemanggil ikan yang berupa lampu tahan air yang diperuntukan bagi para nelayan penghobi mancing di laut, danau maupun sungai, untuk menangkap ikan. Lacuba dioperasikan dengan cara dicelupkan ke dalam air. Lacuba yang berfungsi untuk penerangan dalam proses penangkapan ikan dan sebagai penarik perhatian ikan sehingga ikan berkumpul mendekati cahaya lampu, sehingga memudahkan menjaringnya dan nelayan dapat meningkatkan hasil tangkapannya dua kali lipat. Namun lacuba tidak bisa digunakan oleh semua nelayan karena harus berdasarkan karakteristik wilayah tangkapan dan harganya pun cukup mahal bagi nelayan kecil.

Selain faktor kekuatan cahaya faktor warna cahaya diyakini akan mempengaruhi respon ikan mengingat kemampuan visual tiap jenis ikan yang tidak sama. Berdasarkan beberapa penelitian tentang pemakaian lampu pada alat penangkapan ikan, dapat diketahui bahwa sumber kekuatan sumber cahaya dan intensitas cahaya mempunyai pengaruh besar dalam usaha memikat ikan. Demikian juga dengan letak lampu di atas permukaan air (surface lamp) dan di dalam air (underwater lamp) serta jarak sumber cahaya dengan permukaan air (Notanubun, J dan W. Patty, 2010). Pada intensitas cahaya yang sama tetapi pada jarak yang berbeda akan memberikan hasil tangkapan yang berbeda pula. Semakin dekat sumber cahaya ke permukaan semakin besar pula hasil tangkapan yang diberikan.

Perbedaan hasil tangkapan menurut spesiesnya disebabkan oleh perbedaan tingkah laku pada masing- masing jenis ikan, yang pertama ada jenis-jenis ikan yang tertarik secara langsung terhadap sinar atau sering disebut ikan fototaksis positif, jika ada di sekitar area penangkapan yang terang dan yang kedua adalah jenis-jenis ikan yang sebenarnya tidak suka kepada cahaya lampu tetapi kehadirannya pada areal penangkapan lebih ini disebabkan oleh kehadiran mangsanya pada daerah penangkapan, ikan yang efektif pada malam hari selalu mengutamakan organ penglihatan dalam mencari makanan dan memiliki kemampuan adaptasi terhadap gelap, indera utama penerima rangsangan cahaya pada ikan adalah mata (Sudirman dan Mallawa, A, 2004).

Di dalam retina mata ikan terdapat fotoreseptor (penerima rangsangan cahaya) yang terdiri dari dua tipe yaitu pigmen cone yang berfungsi untuk dalam kondisi terang/intensitas tinggi dan pigmen rod yang berfungsi untuk dalam kondisi gelap, periode surut terjadi setelah mendekati tengah malam sedangkan berbagai jenis organisme lebih banyak tertangkap karena mereka lebih aktif mencari makan pada waktu sebelum tengah malam hingga waktu dini hari (Sudirman, dkk, 2003). Berhasilnya suatu cahaya untuk menarik dan mengumpulkan ikan tergantung pada beberapa faktor, yaitu (Sulaiman, M., I. Jaya.,M.S Dan Baskoro, 2006). 
(1) Ikan yang tertangkap aktif pada malam hari, (2) Air dalam keadaan cukup jernih, (3) Tidak ada cahaya yang lain dari cahaya lampu, dan (4) Kedalaman air cukup sehingga tidak ada pemantulan dari dasar perairan.

Ikan mendekati cahaya lampu karena ikan tersebut memang bersifat fototaksis positif. Namun tidak semua cahaya dapat diterima oleh mata ikan. Cahaya yang dapat diterima memiliki panjang gelombang pada interval $4.000-7.500 \mathrm{~nm}$. Penetrasi cahaya dalam air sangat erat hubungannya dengan panjang gelombang yang dipancarkan oleh cahaya tersebut. Semakin besar panjang gelombangnya maka akan semakin kecil daya tembusnya ke dalam perairan (Puspito dkk, 2015).

Secara sifatnya ikan dibagi menjadi dua yakni fototaxis positif dimana ikan tertarik dengan rangsangan cahaya dan fototaxis negatif yaitu ikan yang tidak tertarik dengan rangsangan cahaya. Penggunaan warna lampu pada alat tangkap bagan (lift net) tentunya akan mempengaruhi ikan hasil tangkapan yang didapatkan. Teori dari beberapa penelitian terdahulu didapatkan hasil bahwa lampu warna putih dan merah kurang memberikan hasil yang maksimal dibandingkan dengan warna lampu yang lain seperti biru dan kuning.

Teknologi lacuba ini menggunakan intensitas cahaya untuk menarik perhatian ikan. Teknologi penangkapan ikan menggunakan alat bantu cahaya sering disebut sebagai light fishing. Sumber cahaya yang digunakan lampu LED yang disusun sehemat dan seefektif mungkin. Cahaya digunakan untuk menarik dan mengkonsentrasikan kawanan ikan pada catchable area yang selanjutnya dengan menggunakan alat tangkap tertentu untuk menangkapnya. Setiap intensitas cahaya yang digunakan oleh nelayan berbeda-beda tergantung pada jenis alat tangkap, spesies target, fishing ground, dan kemampuan finansial dari nelayan. Dari semua alat tangkap di atas, hanya bagan tancap yang menggunakan lampu yang berfungsi sebagai alat pengumpul ikan. Bagan tancap merupakan alat tangkap pasif, dimana alat ini berupa bangunan di tengah laut dengan jaring di bawahnya, jaring akan diangkat setelah banyak ikan yang berkumpul di tengah bagan.

Cahaya dapat merangsang ikan untuk datang dan berkumpul di sekitar sumber cahaya atau dikenal dengan fototaxis positif. Fungsi cahaya dalam penangkapan ikan ini adalah untuk mengumpulkan ikan sampai pada suatu catchable area tertentu, lalu penangkapan dilakukan dengan alat jaring maupun pancing. Penggunaan lampu untuk penangkapan ikan saat ini mengalami perkembangan yang sangat pesat, hampir semua tempat yang terdapat kegiatan perikanan laut, dapat dipastikan terdapat lampu yang digunakan untuk penangkapan ikan (Usman dan Brown, A, (2006).

Lampu pengumpul ikan yang digunakan oleh kelompok nelayan bagan tancap di Kecamatan Sungai Kunyit masih menggunakan lampu petromak dengan bahan bakar minyak tanah. Cahaya lampu petromak cenderung lebih redup dan tidak mampu menembus air laut sampai kedalaman 5 sampai dengan 10 meter. Selain itu, hampir setiap hari terjadi kerusakan pada lampu petromak terutama pada kaos lampu sebagai sumber cahaya.

Kelompok nelayan bagan tancap di Kecamatan Sungai Kunyit sebagian besar masih menggunakan lampu petromak sebagai alat bantu pengumpul ikan. Lampu petromak cenderung kurang efisien dan kurang efektif untuk mengumpulkan ikan. Lampu pengumpul ikan yang digunakan oleh kelompok nelayan bagan tancap di Kecamatan Sungai Kunyit masih menggunakan lampu petromak dengan bahan bakar minyak tanah. Cahaya lampu petromak cenderung lebih redup dan tidak mampu menembus air laut sampai kedalaman 5 meter. Selain itu, hampir setiap hari terjadi kerusakan pada lampu petromak terutama pada kaos lampu sebagai sumber cahaya. Nelayan bagan tancap di Kecamatan Sungai Kunyit juga mengalami permasalahan tentang aplikasi teknologi lampu yang kurang efisien. 
Dimana dalam penggunaannya di bantu dengan genset yang diletakkan 50-125 meter dari bagan tancap disambungkan leat kabel untuk menyalakan lampu dengan daya 500-1000 watt. Hanya saja penggunaan lampu yang diletakkan di atas air, $70 \%$ cahaya yang dipencarkan dipantulkan lagi ke atas oleh permukaan air. Berdasarkan hasil penelitian yang dilakukan oleh BBPPI Semarang (2007) mengatakan bahwa penurunan nilai luminasi cahaya mencapai $\pm 99 \%$ pada lampu galaxy 400 watt setelah berkas cahaya menembus permukaan air laut.

Sinar lampu petromaks jika diperhatikan juga berwarna kuning yang mudah terserap, ditambah lagi posisi lampu yang berada di atas permukaan air atau di atmosfer sehingga jumlah cahaya yang masuk kedalam perairan hanya sedikit, sebagian besar terserap dan dipantulkan oleh permukaan air, ditambah lagi dengan adanya gelombang yang menyebabkan cahaya lampu petromaks menjadi tidak stabil (flickerring effect) yaitu efek cahaya yang tidak stabil atau goyang karena adanya gelombang sehingga menakutkan ikanikan, yang pada akhirnya tidak banyak ikan yang mau mendekati kelong petromaks (Patty W dan Puspito G, 2006).

Maksud dari program pengabdian masyarakat ini adalah untuk meningkatkan hasil tangkapan ikan nelayan bagan tancap di Kecamatan Sungai Kunyit melalui penerapan teknologi lampu celup bawah air berbasis lampu LED. Sedangkan tujuan khusus dari kegiatan pengabdian kepada masyarakat ini adalah:

1. Mengetahui hasil tangkapan ikan pada bagan tancap yang beroperasi di perairan Sungai Kunyit dengan alat bantu lampu celup bawah air.

2. Meningkatkan efektifitas operasi penangkapan ikan pada bagan tancap di Kecamatan Sungai Kunyit dalam penerapan teknologi lampu bawah air.

3. Membangun kesepahaman nelayan bagan tancap dalam pengelolaan sumberdaya ikan.

4. Pemberdayaan nelayan melalui pelatihan, operasional dan perawatan dalam upaya meningkatkan pengetahuan dan keterampilan nelayan dalam penggunaan Lacuba.

\section{Metodologi}

Pelaksanaan kegiatan pengabdian ini dilaksanakan dalam beberapa tahap yaitu tahap pertama perancangan dan pembuatan alat lampu bawah air, tahap kedua melaksanakan diskusi kelompok terbatas, tahap ketiga uji coba dan pelaksanaan program, tahap keempat evaluasi program. Program dilaksanakan selama 4 bulan yaitu dari bulan September Desember 2018.

Kegiatan sosialisasi dan pelatihan dilakukan di pulau Temajo, kecamatan Sungai Kunyit, kabupaten Mempawah. Dalam pelaksanaannya, dilakukan kerjasama dengan Himpunan Nelayan Seluruh Indonesia (HNS1) Kabupaten Mempawah. Desain lampu celup yang baik dikemas secara khusus dalam satu wadah plastik dan telah teruji tahan hingga kedalaman 15 meter. Lampu dapat dipakai pada perahu, bagan tancap maupun bagan apung dan dicelupkan kedalam air dengan penambahan beberapa peralatan untuk menambatkan kabel pada perahu maupun Bagan. Di bawah lacuba, dapat diletakkan jaring, kail ikan maupun alat tangkap ikan lainnya. Lacuba diletakan kira-kira $2-5$ meter dibawah perahu/bagan. Lacuba dilengkapi dengan sistem elektronik, kabel penghubung dan dioperasikan dengan sumber arus searah dari battery/accu untuk menghasilkan cahaya dengan intensitas yang terang. Dari hasil survei yang telah dilakukan oleh para peneliti BPPT diberbagai daerah di seluruh Indonesia, telah diperoleh informasi bahwa tangkapan ikan para nelayan bisa mencapai 2 sampai 3 kali jika dibanding dengan menggunakan cahaya lampu petromaks, dari sisi kekuatan dan ketahanan lampu ini dapat diandalkan.

Sebagai tindak lanjut dari kegiatan pengabdian kepada masyarakat ini, juga diberikan 
materi sosialisasi yang berupa hal-hal sebagai berikut:

\section{a. Teknik dan pemakaian dan perawatan lacuba:}

1. Sebelum memakai Lacuba pastikan bahwa accu sudah di charge (dalam keadaan penuh).

2. Hubungkan kabel hitam dengan terminal (-) negatif accu $12 \mathrm{~V} / 70 \mathrm{Ah}$.

3. Hubungkan kabel biru dengan terminal (+) positif accu.

4. Turunkan Lacuba sampai batas kedalaman yang diinginkan (max. 15-18 meter).

5. Hindari terkena sinar matahari langsung (hindari tempat panas).

6. Jangan sesekali membuka cover lacuba kalau tidak terlalu penting, untuk menghindari kebocoran lacuba terhadap air.

7. Jangan sampai membanting/memukulkan lacuba ke benda keras.

8. Disarankan untuk menyalakan lampu setelah terendam air, jangan menyalakan lacuba dalam keadaan tidak dalam air, karena mempercepat umur modul elektronik lacuba.

9. Disarankan menggunakan bandul pemberat $1 \mathrm{Kg}$ dan $3 \mathrm{Kg}$ untuk arus laut yang cukup deras.

10. Jangan menyalakan lacuba di atas permukaan air lebih dari 30 menit.

11. Lacuba hanya bias dinyalakan pada tegangan 12 Volt, jika digunakan tegangan lebih kecil atau lebih besar akan merusak modul elektronik Lacuba.

\section{b. Lacuba dalam keadaan lengkap terdiri dari :}

- Lacuba : Bagian bodi, bagian rumah lampu, bagian inverter elektronik dan kabel.

a Karet pengaman.

a Bandul pemberat.

\section{Keterangan:}

1. Lampu PL-C $18 \mathrm{~W}$

2. Klem kawat "M"

3. Ring "O"

4. Modul La CUBA

5. Kabel NYYHY 2 x 2,5 mm

6. Cover lampu

7. Holder

8. Penutup holder

9. Karet pelindung

10. Bandul pemberat

11. Pengunci bandul

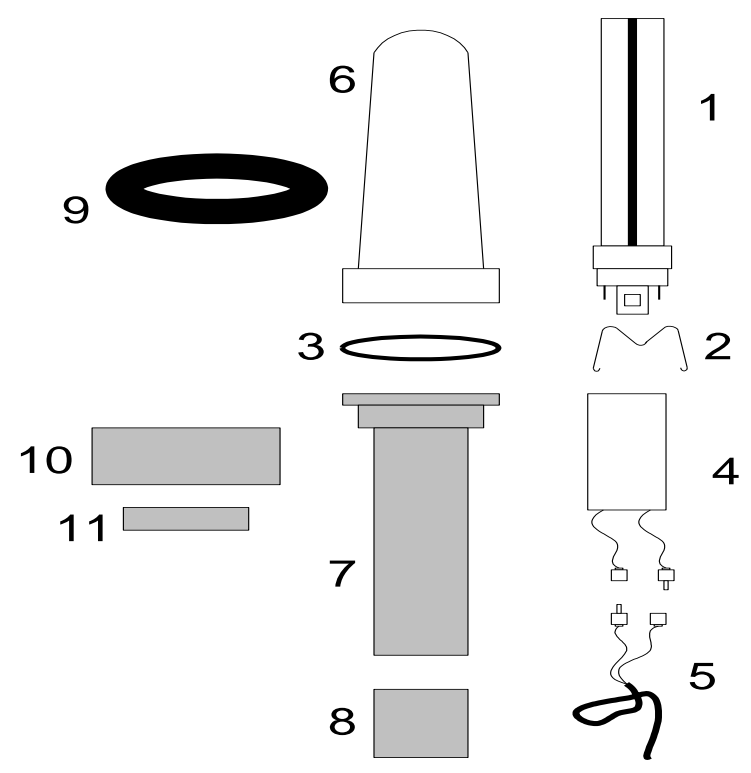

Gambar 1. Bagian Dari Komponen-Komponen Lacuba

\section{c. Penggunaan dan perawatan baterai/accu:}

1. Periksa terminal baterai/accu, ketinggian air accu secara berkala minimal sebulan sekali

2. Bila terminal/ terminal berkarat cucilah terminal dengan menggunakan air panas dan kemudian dioleskan sedikit oli bekas.

3. Jika permukaan air accu turun hingga mendekati garis lower level, tambahkan hanya dengan air accu (botol biru), jangan tambahkan yang merah.

4. Untuk pengisian accu:

a. Jika jumlah lacuba maksimal yang dapat disambungkan dengan baterai (70 $\mathrm{AH})$ adalah 2 unit. 
b. Jika accu digunakan dengan lacuba 18 watt 2 unit selama 7 jam maka waktu pengisian (charging) sama dengan waktu pemakaian yaitu 7 jam.

c. Jika accu disambungkan dengan lacuba lebih sedikit, waktu pengisian lebih pendek.

5. Selalu men-charge/strom baterai setelah digunakan.

6. Bila baterai/accu telah diisi accu zuur dan tidak dipergunakan dalam waktu lama, lakukan charge 1 bulan sekali.

Penggunaan lampu ditambah aki $(a c c u)$, selain merupakan suatu alternatif yang paling murah juga berbasiskan teknologi. Dengan penggunaan lampu ini bukan berarti harus meninggalkan kebudayaan nelayan menangkap ikan pada bagan tancap dengan menggunakan petromak. Hal ini sudah kami perhatikan di semua daerah Kalbar hingga saat ini sebagian besar cara yang dilakukan untuk penangkapan ikan adalah dengan cara tradisional, khususnya dengan menggunakan :"lampu petromak" sebagai andalannya. Adapun kelemahan-kelemahan yang dimiliki lampu petromak minyak tanah ini adalah:

1. Tidak tahan terpaan angin yang kencang.

2. Lampu akan mati jika turun hujan

3. Menggunakan minyak tanah yang dapat mencemarkan air laut dan mengeluarkan $\mathrm{CO} 2$.

4. Lampu tidak dapat bertahan jika terjadi ombak besarnya pengoperasian cukup mahal.

5. Sangat menbutuhkan pemeliharaan yang rutin setiap habis dipakai.

6. Bila tekanan berkurang cahayanya meredup, sehingga harus berkali-kali dipompa

7. Sarung petromak tidak tahan pada kekuatan api yang cukup besar sehingga terlalu sering mengganti sarung (perlu cadangan).

8. Dapat meledak dan bahkan memakan korban jiwa

Dalam hal ini mengatasi kendala-kendala seperti tersebut diatas, lampu nelayan (lacuba) memiliki beberapa keunggulan sebagai berikut:

1. Lampu diapungkan dipermukaan air laut dengan sudut arah pancaran sinar lampu dapat diatur sehingga berkemampuan radius pancaran cahaya luas/jauh.

2. Lampu "celup" dapat digunakan dengan kedalaman panjang kabel hingga 20 meter, yang dapat menerangi di dalam laut sampai dengan kedalaman radius 20 meter karena terdapat pemberat 1 dan $3 \mathrm{~kg}$.

3. Lampu tahan terhadap air, ombak besar dan angin kencang.

4. Waktu operasi cukup lama antara 8 - 10 jam, dengan intensitas/kuat cahaya tetap.

5. Tahan terhadap benturan, karena bahan utamanya terbuat dari PVC yang memiliki daya elastisitas tinggi.

6. Cahaya lampu lebih terang dan terdapat pilihan jenis warna cahaya (putih dan merah kekuning-kuningan), sesuai kebutuhan (warna cahaya yang disenangi ikan = sifat fototaksis).

7. Pemeliharaan sangat mudah dengan hanya memerlukan pengisian air baterai beberapa bulan sekali dan selalu dicharger.

8. Pengoperasiannya sangat sederhana dengan hanya menyambungkan aki dengan lampu maka lampu akan menyala, kemudian diapungkan atau ditenggelamkan di atas ataupun di dalam permukaan air laut.

9. Ramah terhadap lingkungan karena tidak menimbulkan polusi karena menggunakan sumber energi yang dapat diperbaharui.

10. Mudah dan murah dalam perawatan serta hemat energi.

Dalam pelaksanaan kegiatan diseminasi teknologi lampu celup bawah air (lacuba) metode yang digunakan adalah partisipatori aktif, yaitu peran aktif dari pihak-pihak yang terlibat, khususnya mitra selama proses pelaksaan kegiatan agar mitra benar-benar memiliki 
kemampuan dalam pengoperasian dan maintenance peralatan yang didesiminasikan. Mitra diharapkan melakukan peran aktif selama proses kegiatan diseminasi, seperti mengikuti pelatihan yang disampaikan tim LPPM Untan dan Dinas Perikanan Dan Kelautan Kabupaten Mempawah, melaksanakan penangkapan ikan di bagan tancap dengan menggunakan teknologi lacuba.

Untuk mencapai tujuan pelaksanaan desiminasi PKM maka dilakukan tahapan kegiatan sebagai berikut:

1. Orientasi lapangan, meliputi: a) Survey lokasi PKM; b) Pernyataan kesediaan mitra; c) Tempat sosialisasi di lokasi mitra.

2. Invetarisir Kebutuhan Desiminasi Teknologi, meliputi: a) Jumlah alat yang akan didesiminasikan; b) Biaya yang Pelatihan; c) Transportasi air menuju bagan tancap;

3. Transfer Pengetahuan Melalui Pelatihan Dan Praktek Penggunaan Produk Teknologi, meliputi: a) Penjelasan tentang perikanan dan kelautan; b) Penjelasan praktis lacuba; c) Demonstrasi peralatan yang akan digunakan.

4. Pelaksanaan Di Lapangan, meliputi: a) Uji coba daya tahan lacuba dengan variasi kedalaman; b) Uji coba ketahanan batere tanpa henti; c) Pelaksanaan dalam proses penangkapan ikan.

5. Monitoring Dan Evaluasi, pada tahapan ini tim desiminasi PKM akan mengunjungi lokasi untuk mendapatkan informasi real terhadap hasil penangkapan ikan setelah menggunakan alat yang didesiminasikan.

6. Pembuatan Laporan dan Publikasi, bagian akhir dari kegiatan ini adalah pelaporan hasil desiminasi dan melakukan publikasi ilmiah baik di media massa maupun jurnal PKM terakreditasi.
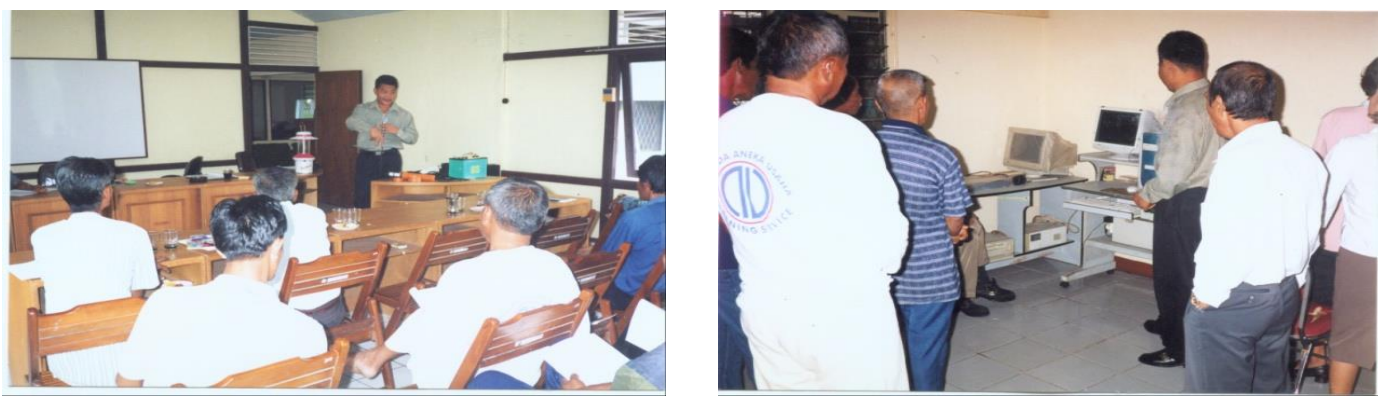

Gambar 2. Sosialisasi Dan Demo Lewat Komputer Penggunaan Lacuba
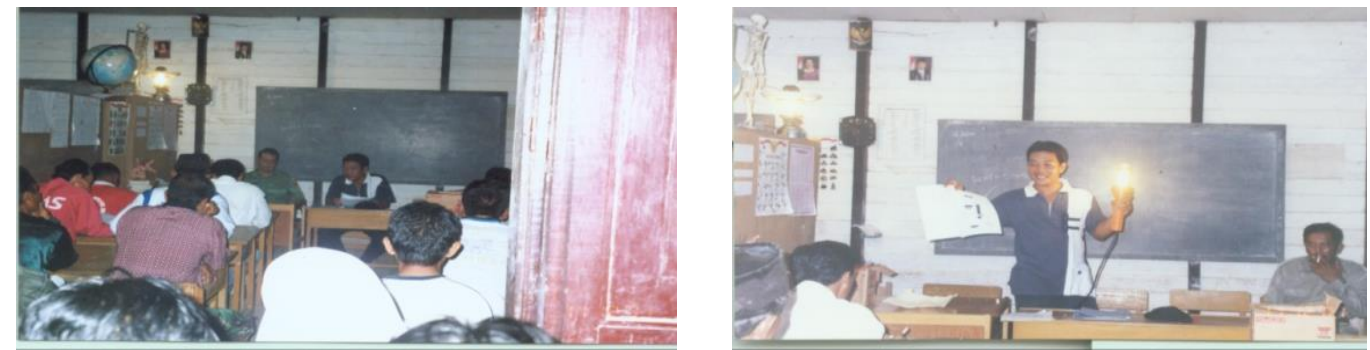

Gambar 3. Memperagakan Teknik Instalasi dan Pemakaian Lacuba 

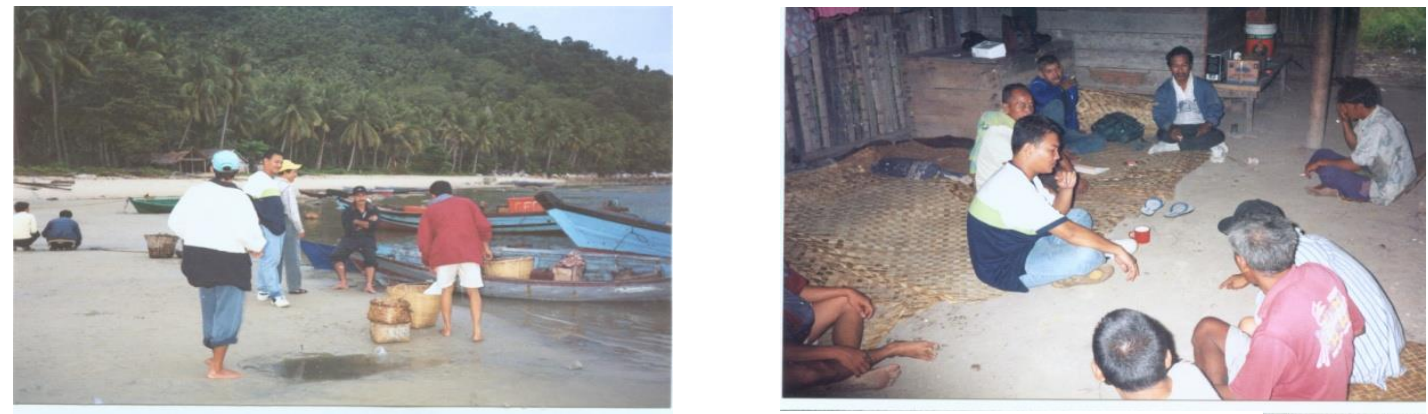

Gambar 4. Ke Pulau Temajo dan Diskusi Penggunaan Lacuba
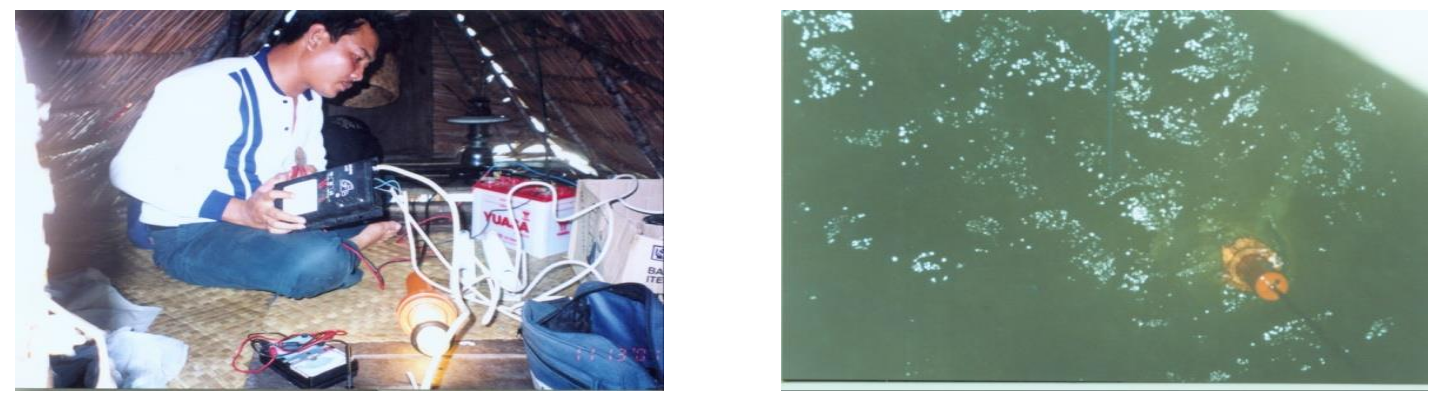

Gambar 5. Setting Lacuba Dan Ujicoba Penangkapan Ikan dan Sotong (cumi)

Dalam mengaplikasi lampu celup bawah air dilaksanakan di perairan Sungai Kunyit dimana setiap setting dilakukan selama 3 jam, disela-sela waktu menunggu 3 jam dilakukan pemantauan terhadap jumlah ikan yang datang menghampiri lampu bawah air. Proses pengoperasian lampu bawah air pada bagan tancap dimulai pukul 19.30 - 04.30, sehingga dalam 1 trip hanya ada 3 kali setting yang dikelompokkan dalam 3 kategori setting 1 (sebelum tengah malam pukul 19.30 - 21.30), setting 2 (saat tengah malam pukul 22.00 - 01.30), dan setting 3 (setelah tengah malam pukul 02.00 - 04.30). Proses pengamatan dilakukan dengan pengamatan langsung dan menggunakan kamera underwater untuk melihat tingkah laku ikan pada kedalaman 3 - $15 \mathrm{~m}$.

Penurunan jaring menggunakan roller sampai kedalaman 15 meter sampai ke dasar perairan dibawah permukaan air, setelah menurunkan jaring Lacuba dan lampu setting dihidupkan. Perendaman jaring tidak selalu sama setiap Hauling karena menunggu ikan yang akan berkumpul di bawah cahaya Lacuba. Selama jaring direndam dilakukan pengamatan secara langsung yaitu pengamatan tanda-tanda ikan berkumpul bawah cahaya lampu dan mengamati keadaan arus, gelombang, dan angin.; kemudian hauling dilakukan jika ikan sudah berkumpul disekitar bawah sumber cahaya Lacuba. Pada tahap ini Lacuba diganti dengan lampu hauling. Jaring angkat secara vertical kerarah permukaan air menggunakan roller dengan perlahan dengan kecepatan maksimum; setelah jaring bagan sampai ke permukaan air, maka hasil tangkapan dapat diambil dengan menggunakan serok sebagai 
alat bantu, kemudian ikan disortir sesuai jenisnya Ikan Teri (Stolephorus sp.), ditimbang kemudian data dicatat pada tabel yang disiapkan.

\section{Hasil dan pembahasan}

\section{A. Hasil}

Dalam metode pelaksanaan diseminasi alat berteknologi ini, mitra berpartisipasi aktif (partisipatori aktif) dalam seluruh rangkaian kegiatan yang dilaksanakan. Mitra benar-benar dapat menyerap ilmu melalui transfer teknologi yang dilakukan oleh tim diseminasi PKM. Keberhasilan dari kegiatan diseminasi PKM ini adalah terjadi transfer ilmu pengetahuan dan teknologi yang pada akhirnya meningkatkan penghasilan mitra. Adapun ringkasan partisipasi aktif dari mitra nelayan adalah sebagai berikut:

1.Mitra mengikuti proses pelatihan, baik materi tentang perikanan dan kelautan, juga mengenai pengetahuan tentang materi alat berteknologi yang disampaikan.

2.Mitra mencoba langsung atau mendemonstrasi pengoperasian saat pelatihan berlangsung baik tata cara mengoperasikan lacuba maupun tata cara charging aki, agar mitra nelayan memahami secara detail dan terampil dalam pengoperasian alat yang akan digunakan.

3.Mitra menyediakan tempat pelatihan dan tempat untuk demonstrasi peralatan yang akan digunakan, juga menyediakan sumber listrik untuk praktek.

4. Mitra mau mengikuti panduan operasional dari alat yang digunakan.

5. Mitra menjalin kerjasama dengan perguruan tinggi (FT Untan) dan pihak-pihak yang terkait lainnya, misalnya pemerintah daerah setempat.

6. Mitra bersedia melaporkan dengan jujur kondisi peralatan yang digunakan saat tim perguruan tinggi membutuhkannya.

7. Mitra melaporkan dengan jujur hasil tangkapan ikan selama mengoperasikan alat yang digunakan, agar tim perguruan dapat melakukan evaluasi.

Selama pelaksanaan program pengabdian di lapangan, dilakukan pengukuran kualitas air untuk mengidentifikasi pengaruh lingkungan terhadap keberhasilan operasi penangkapan ikan. Berdasarkan hasil pengukuran kualitas air diperoleh informasi bahwa perairan di sekitar bagan tancap memiliki kisaran suhu $26.50 \mathrm{C}$ - 310C dengan salinitas kisaran $18 \mathrm{ppt}-$ 33 ppt dan tingkat kecerahan berkisar 1,86-2,075 m. Salinitas adalah suatu tingkatan kadar keasinan dari garam di dalam air. Keberadaan salinitas ada di seluruh kandungan air, bahkan air tawar sekalipun yang tidak memiliki rasa asin sebenarnya memiliki salinitas. Hal ini dikarenakan kandungan salinitas dalam air tawar sangat sedikit, kurang dari 0,05ppt (part-per- 
thousand). Jika lebih dari itu maka akan masuk kategori air payau dan bisa menjadi air asin (saline) jika kandungannya berada di 3ppt sampai 5ppt. Tempat-tempat perairan di darat seperti sungai, danau, kali, sumur, air tanah memiliki salinitas yang rendah. Sedangkan air laut memiliki salinitas yang tinggi. Pengukuran salinitas secara manual adalah menggunakan alat ukur Tester EZ9909 Salt, Salinity Meter Digital AR8012 dan Salinity Refractometer.
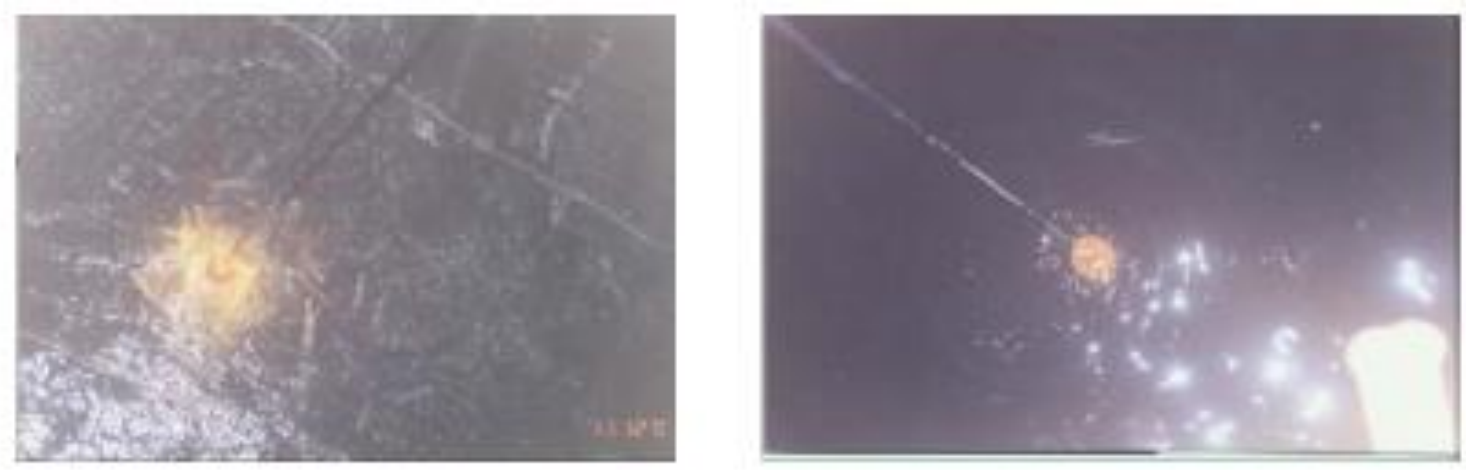

In

pada perairan. Pengambilan data kekeruhan dilakukan dengan memasukkan turbiditymeter pada tiga kedalaman yaitu 5, 10, dan 15 meter. Secara otomatis alat ini akan membaca nilai kekeruhan suatu perairan. Kekeruhan dinyatakan dalam satuan NTU (Nephelometric Turbidity Units). Semakin banyak padatan tersuspensi dalam air, air terlihat semakin keruh dan semakin tinggi pula nilai NTU. Untuk mendapatkan nilai kekeruhan suatu perairan dilakukan pengukuran mengunakan alat turbidity meter yang mana pada dasarnya adalah pengukuran intensitas cahaya yang ditranmisikan sebagai fungsi dari konsentrasi fase terdispersi, bilamana cahaya dilewatkan melalui suspensi maka sebagian dari energi radiasi yang jatuh dihamburkan dengan penyerapan, pemantulan, dan sisanya akan ditranmisikan. Dalam pengambilan data kecerahan metode yang digunakan yaitu visualisasi.Kondisi cuaca sangat berpengaruh terhadap keberhasilan operasi penangkapan ikan, dimana arus, angin dan perbedaan suhu perairan akan mendorong terjadinya upwelling. Jika upwelling terjadi maka pengoperasian alat dihentikan sementara sambil menunggu kondisi perairan yang kondusif. Kondisi cuaca sangat berpengaruh terhadap kondisi perairan dan kondisi perairan juga berpengaruh pada distribusi ikan. 
Jenis ikan yang tertangkap selama pelaksanaan program pengabdian dapat digolongkan menjadi tiga yaitu ikan pelagis, demersal dan reef associated. Total hasil tangkapan selama percobaan lampu celup bawah air untuk satu bagan tancap sebesar $91 \mathrm{~kg}$ yang sebelumnya nelayan menggunakan lampu petromak mendapatkan $59 \mathrm{~kg}$ untuk satu bagan tancap, sedangkan jenis ikan yang dominan tertangkap berturut-turut adalah jenis ikan teri (Stolephorus spp), ikan selar (Selaroides spp), ikan pepetek (Leiognathus spp), cumi-cumi (Loligo $s p$ ), ikan kembung (Rastrelliger spp). Kelompok ikan lainnya yang tertangkap pada bagan tancap adalah udang mantis (Squilla spp), udang (Penasesus sp), rajungan (Portunus $s p$ ), gurita (Octopus), sotong (Sepia sp), ubur - ubur (Aurelia sp), ikan beloso (Saurida $s p$ ), ikan kakap (Lutjanus spp), ikan Lemuru (Sardinella spp), ikan julung-julung (Hemirahmpus $s p$ ), ikan sembilang (Plotosus sp), ikan belanak (Mugil sp), ikan alu-alu (Sphyraena spp), ikan bulu ayam (Thryssa sp), ikan sebelah (Psettodidae sp), ikan putihan (Caranx sp), ikan keeper (Scatophagus sp), ikan layur (Trichiurus sp). Kelompok ikan ini mempunyai hasil tangkapan yang sangat kecil per jenisnya.

Selama pelaksanaan uji coba di bagan tancap ditemukan 23 jenis ikan yang tertangkap. Pengamatan ini juga memberikan informasi bahwa jenis ikan ikan teri, selar, pepetek, cumi-cumi, kembung merupakan jenis ikan yang selalu tertangkap di bagan tancap walaupun dilakukan perbedaan perlakuan intensitas selama penggunaan lampu celup bawah air.
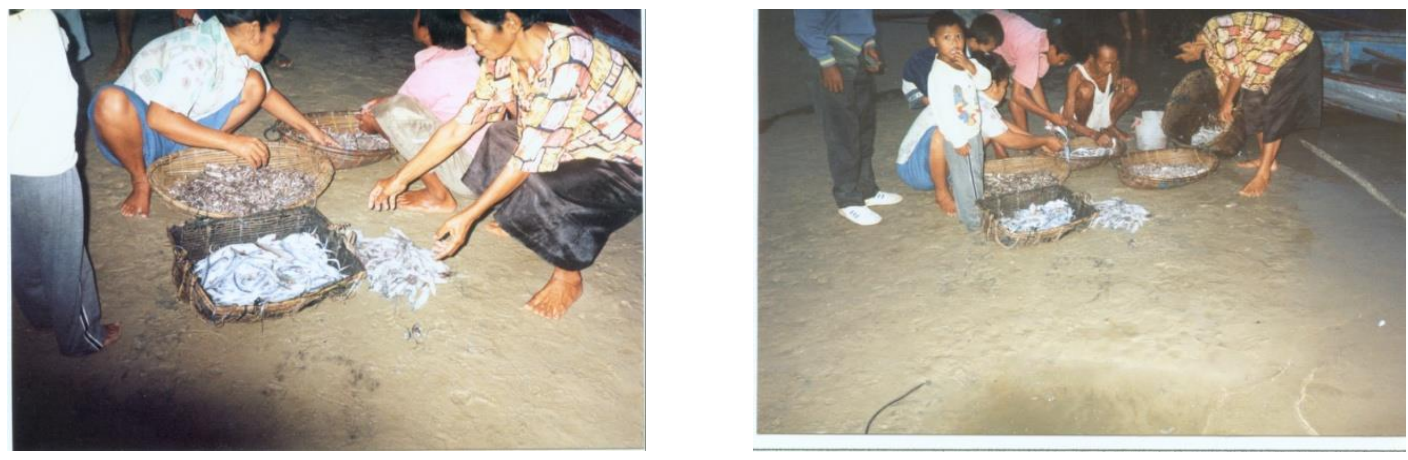

Gambar 7. Hasil Tangkapan Dari Bagan Tancap Menggunakan Lacuba

\section{B. Pembahasan}

Ikan teri memiliki sifat bergerombol dalam jumlah yang banyak dan memiliki sifat fototaksis positif terhadap sumber cahaya. Ikan teri diduga mempunyai sifat fototaksis positif yang sangat tinggi, sedangkan spesies lainnya disamping sifat fototaksis juga karena dorongan mencari makan. Faktor lainnya adalah perbedaan jumlah ikan dalam gerombolannya. Pada bagan tancap distribusi ikan lebih terkonsentrasi pada kedalaman $2-4$ m. Jenis-jenis ikan yang berada pada kedalaman tersebut antara lain adalah pepetek, ikan teri. Jenis-jenis yang senang dipermukaan air adalah kepiting rajungan.

Organisma fototaksis (+) rebon tergolong organisma nokturnal yang mendiami dasar perairan pantai, muara sungai dan teluk. Pepetek sebenarnya berada pada daerah benthopelagik pada kedalaman antara 10-110 m. Teri selalu berada di kedalaman tertentu pada siang hari dan bergerak ke permukaan air pada malam hari. Selar merupakan jenis ikan mesopelagis yang hidup di bagian dekat permukaan maupun dasar perairan. Tembang dikenal sebagai ikan pelagis permukaan yang menyukai perairan terbuka hingga kedalaman 150 m. Bulu ayam hidup di daerah pantai yang dekat dengan muara sungai dan tergolong ikan pelagis kecil yang hidupnya cenderung di dasar. Adapun kembung merupakan ikan pelagis yang hidup pada kedalaman perairan antara 20-90 m. 
Kesembilan organisma tersebut hidup bergerombol dan sangat tertarik pada cahaya, karena pada daerah tersebut terdapat plankton yang menjadi makanannya. Selain itu, adanya rangsang cahaya pada malam hari menyebabkan organisma fototaksis $(+)$ tertarik ke daerah yang diterangi oleh cahaya lampu di bawah bagan untuk membentuk gerombolan agar lebih aman dari incaran predator.

Adapun cumi-cumi digolongkan sebagai organisma pelagis, tetapi kadang-kadang digolongkan sebagai organisma demersal karena sering terdapat di dasar perairan. Cumicumi melakukan pergerakan diurnal pada siang hari dan berkelompok dekat dasar perairan. Selanjutnya, cumi-cumi akan menyebar pada kolom perairan pada malam hari. Cumi-cumi umumnya mendekati cahaya dan sering ditangkap dengan menggunakan bantuan cahaya.

Penentuan waktu pengoperasian bagan perlu dilakukan karena berhubungan dengan waktu makan ikan. Ikan yang lapar akan lebih terpikat oleh cahaya dari pada ikan kenyang, sehingga waktu ikan lapar harus diketahui karena mempengaruhi keberhasilan operasi penangkapan ikan dengan bagan.

Berat hasil tangkapan bagan ternyata berbeda berdasarkan waktu penangkapannya. Ini dibuktikan dengan hasil analisis sidik ragam yang menunjukkan bahwa waktu operasi penangkapan memberikan pengaruh yang nyata terhadap berat hasil tangkapan. Berat hasil tangkapan tertinggi, baik organisma fototaksis $(+)$ maupun predator, terjadi pada waktu operasi penangkapan antara pukul 19.30-21.00. Selanjutnya berat hasil tangkapan semakin menurun hingga pukul 00.00-03.00. Berat tangkapan kembali sedikit meningkat antara pukul 03.00-04.00. Ikan lebih aktif dan menunjukan sifat fototaksis yang maksimum sebelum tengah malam. Waktu operasi penangkapan antara pukul 19.30-21.00 merupakan waktu adaptasi penglihatan ikan dari keadaan terang ke gelap. Pada waktu tersebut keadaan lingkungan yang berubah menjadi gelap mengakibatkan ikan tertarik oleh cahaya buatan. Pada umumnya ikan lebih aktif dan menunjukan sifat fototaksis yang maksimum sebelum tengah malam. Ini menjadi penyebab kenapa hasil tangkapan bagan antara pukul 19.30-21.00 lebih banyak dibandingkan dengan waktu-waktu lainnya.

Posisi lampu petromaks yang berada di atas air laut memperburuk efek penyinaran lampu ini, karena bergelombangnya permukaan laut menyebabkan sinar yang dilihat ikan bawah air tidak stabil atau flickering effect. Keadaan penyinaran yang tidak stabil inilah yang menimbulkan efek takut bagi ikan-ikan di dalam air dan akhirnya mereka menjauh. Disamping jumlah sinar yang mampu menembus kedalam perairan yang sangat kecil. Hasil tangkapan menggunakan lacuba lebih tinggi dibandingkan dengan peletakkan lampu di atas air. Posisi lampu yang berada di atas air laut memperburuk efek penyinaran lampu karena bergelombangnya permukaan laut yang menyebabkan sinar tidak stabil atau flickering effect.

\section{Simpulan}

Berdasarkan hasil pelaksanaan program dapat disimpulkan bahwa nelayan bagan tancap yang terdiri dari 20 orang telah mengerti dan mampu menerapkan teknologi lampu celup bawah air setelah mengikuti program pengabdian ini. Kelompok nelayan bagan tancap menginginkan adanya teknologi yang mampu meningkatkan hasil tangkapan ikan, namun tidak merusak lingkungan.Teknologi lampu bawah air sangat efektif untuk meningkatkan hasil tangkapan ikan. Hal ini dibuktikan dengan meningkatnya hasil tangkapan ikan sekitar 65\% dibandingkan dengan menggunakan lampu petromak.

Penggunaan lampu celup bawah air pada bagan tancap yang diterapkan dalam kegiatan pengabdian ini terlaksana dengan baik yang ditunjukkan adanya peningkatan 
hasil tangkapan ikan yang lebih banyak dibandingkan dengan menggunakan lampu petromak. Penggunaan teknologi lampu bawah air cukup rumit bagi nelayan tradisional, untuk itu perlu pendampingan yang inten agar berjalan dan lebih berhasil.

Dengan alih teknologi dalam kegiatan pengabdian ini, tidak berarti permasalahan sudah selesai namun masih diperlukan pembinaan terhadap manfaat dari teknologi. Dengan demikian proses tahapan alih teknologi yang berkelanjutan di pedesaan sangat diprioritaskan, terutama manfaat dalam membina sumber daya manusia dalam mendukung ke arah kegiatan produktif. Keberhasilan teknologi di pedesaan banyak didukung oleh penguasaan teknologi yang banyak memberikan manfaat dalam meningkatkan taraf hidup dan kesejahteraan masyarakat pedesaan, hal itu hanya bisa dicapai kalau sumber energi yang tersedia dapat mengembangkan dan mendukung ke arah potensi ekonomi pedesaan.

\section{Ucapan terimakasih}

Ucapan terimakasih kami sampaikan kepada Dinas Kelautan Dan Perikanan, HSNI Kabupaten Mempawah, masyarakat nelayan di Kecamatan Sungai Kunyit, Lembaga Penelitian dan Pengabdian Kepada Masyarakat (LPPKM) Universitas Tanjungpura, serta semua stakeholder yang telah membantu pelaksanaan kegiatan pengabdian ini.

\section{Daftar pustaka}

Balai Besar Pengembangan Penangkapan Ikan. (2007). Klasifikasi Alat Penangkapan Ikan. Balai Besar Pengembangan Penangkapan Ikan. Semarang.

Brown, A., Isnaniah, \& Domitta, S, (2013). Perbandingan Hasil Tangkapan Kelong (Liftnet) menggunakan Lampu Celup Bawah Air (LACUBA) dan Petromaks di Perairan Desa Kote Kecamatan Singkep Kabupaten Lingga Propinsi kepulauan Riau. Akuatika.

Bustari, (2004). Pengaruh Cahaya Lampu Dan Lama Penyinaran Terhadap Komunitas Ikan Pada Penangkapan Dengan Bagan Apung di Perairan Sungai Pisang Padang Sumatera Barat, Tesis Pasca Sarjana Universitas Andalas, Padang, 171 hal, (tidak diterbitkan).

Notanubun, J dan W. Patty. (2010). Perbedaan Penggunaan Intensitas Cahaya Lampu Terhadap Hasil Tangkapan Bagan Apung Di Perairan Selat Rosenberg Kabupaten Maluku Tenggara Kepulauan Kei. Jurnal Perikanan dan Kelautan Vol. VI-3, Desember 2010 .

Patty W. (2010). Analisa Sebaran Iluminasi Cahaya Petromaks dengan Perlakuan Bertudung dan Tanpa Tudung. Jurnal Perikanan dan Kelautan Tropis. 6(3):156159.

Puspito G. (2006). Sebaran Iluminasi Cahaya Petromaks dan Penerapannya pada Perikanan Bagan. Prosiding Seminar Nasional Perikanan Tangkap. Bogor: Departemen Pemanfaatan Sumberdaya Perikanan, Fakultas Perikanan dan Ilmu Kelautan, Institut Pertanian Bogor. 174-185.

Puspito G. (2012). Pengaruh Pemusatan Cahaya terhadap Efektivitas Bagan. Indonesian Journal of Fisheries Science and Technology. 7(2): 5-9.

Setiawan, F., Sulistiyanti, S. R., \& Sadnowo, A. (2015). Analisis Pengaruh Medium Perambatan terhadap Intensitas Cahaya Lacuba (Lampu Celup Bawah Air). Rekayasa dan Teknologi Elektro.

Sudirman, M., S. Baskoro, A. Purbayanto, D.R. Monintja, M.Jufri dan T.Arimoto. (2003). 
Adaptasi Retina Mata Ikan Layang (Decapterus ruselli) terhadap Cahaya Dalam Proses Penangkapan Pada Bagan Rambo Di Selat Makassar. Jurnal Ilmu-Ilmu Perairan dan Perikanan Indonesia. Jilid 10, Nomor 2 hal 85-92.

Sudirman \& Natsir. (2011). Perikanan Bagan dan Aspek Pengelolaannya. UMM Press: Malang.

Sudirman \& Mallawa, A. (2004). Teknik penangkapan ikan. Rineka Cipta, Jakarta.

Sulaiman, M., I. Jaya., M.S. Baskoro. (2006). Studi Tingkah Laku Ikan Pada Proses Penangkapan Dengan Alat Bantu Cahaya Suatu Pendekatan Akustik. Ilmu Kelautan. Maret. Vol. 11 (1) : $31-36$.

Usman dan Brown, A, (2006). Hubungan Hasil Tangkapan Bagan Apung Dengan Kondisi Lingkungan Pada Senja dan Tengah malam di perairan Sungai Pisang Sumatera Barat, Jurnal Perikanan dan Kelautan volume 11 no 1, Hal 63-64. 